- FINANSE I PRA WO F I NA NSO WE.

- Journal of Finance and Financial Law

Wrzesień/September 2017 • vol. 3(15): 107-121

http://dx.doi.org/10.18778/2391-6478.3.15.09

\title{
PRAWNE I EKONOMICZNE ASPEKTY OCHRONY KONSUMENTA NA RYNKU TERMINOWYM W POLSCE I NA ŚWIECIE
}

\author{
Krystian Piotr Wodniak \\ Wydział Nauk Ekonomicznych i Zarządzania \\ Uniwersytet Mikołaja Kopernika w Toruniu
}

\begin{abstract}
Streszczenie
W referacie przedstawione zostały prawne i ekonomiczne aspekty ochrony konsumenta na rynku terminowym w Polsce i na świecie, a także problemy istotne dla rozszerzenia tego tematu. Celem referatu jest wyjaśnienie kwestii nadzoru oraz refleksje na temat możliwości informowania konsumenta na polskim rynku terminowym, ponadto zobrazowanie jak ochrona prawna i ekonomiczna wygląda w Unii Europejskiej i na świecie. Omówiony został także wątek ogólnych relacji pomiędzy klientem, a podmiotami inwestycyjnymi (polskimi i zagranicznymi), ponadto jak takie relacje wpływają na klarowność rynku terminowego.
\end{abstract}

Słowa kluczowe: rynki finansowe, rynek terminowy, giełda.

JEL Class: G10, G19. 


\section{WPROWADZENIE}

W ostatnich latach możemy zaobserwować znaczący wzrost zainteresowania rynkami terminowymi w Polsce i na świecie. Zarówno chęć spekulacyjnego zarobku czy bezpieczniejszego ulokowania nadwyżek kapitału, z roku na rok powodują wzrost liczby klientów podmiotów brokerskich. Rozwój rynku, a także wzrost liczby instrumentów finansowych, szeroki wachlarz podmiotów inwestycyjnych, agresywny marketing, a także fakt występowania asymetrii informacji pomiędzy konsumentem a podmiotem inwestycyjnym sprawia, że niezbędnym więc wydaje się jest tworzenie nowych regulacji prawnych. Regulacje te pierwotnie mają na celu zapewnienie konsumentom swobodniejszego uczestnictwa na rynku terminowym poprzez zwiększanie ich poziomu wiedzy, świadomości bądź informowanie o prawach im przysługującym. Równolegle z regulacjami prawnymi, wprowadzenie pewnych rozwiązań ekonomicznych może sprawić, że konsumenci będą w mniejszym stopniu narażeni na nieuczciwe praktyki niektórych podmiotów inwestycyjnych.

Podstawę prawną funkcjonowania rynku terminowego w Polsce stanowi 9 wymienionych poniżej aktów prawnych [Akty prawne rynku kapitałowego, dostęp: 14.03.2017]:

- Ustawa z dnia 21 lipca 2006 r. o nadzorze nad rynkiem finansowym,

- Ustawa z dnia 12 czerwca 2015 r. o zmianie ustawy o nadzorze nad rynkiem kapitałowym oraz niektórych innych ustaw,

- Ustawa z dnia 29 lipca 2005 r. o nadzorze nad rynkiem kapitałowym,

- Ustawa z dnia 5 grudnia 2014 o zmianie ustawy o obrocie instrumentami finansowymi oraz niektórych innych ustaw,

- Ustawa z dnia 29 lipca 2005 r. o obrocie instrumentami finansowymi,

- Ustawa z dnia 29 lipca 2005 r. o ofercie publicznej i warunkach wprowadzania instrumentów finansowych do zorganizowanego systemu obrotu o spółkach,

- Ustawa z dnia 27 maja 2004 r. o funduszach inwestycyjnych i zarządzaniu alternatywnymi funduszami inwestycyjnymi,

- Ustawa z dnia 15 stycznia 2015 r. o obligacjach,

- Ustawa z dnia 26 października 2000 r. o giełdach towarowych.

Konsument na rynku terminowym to klient podmiotu maklerskiego, brokerskiego, który korzysta $\mathrm{z}$ tychże usług w celu dokonywania transakcji na rynku. Schemat 1 prezentuje podział pionowy rynku finansowego. 


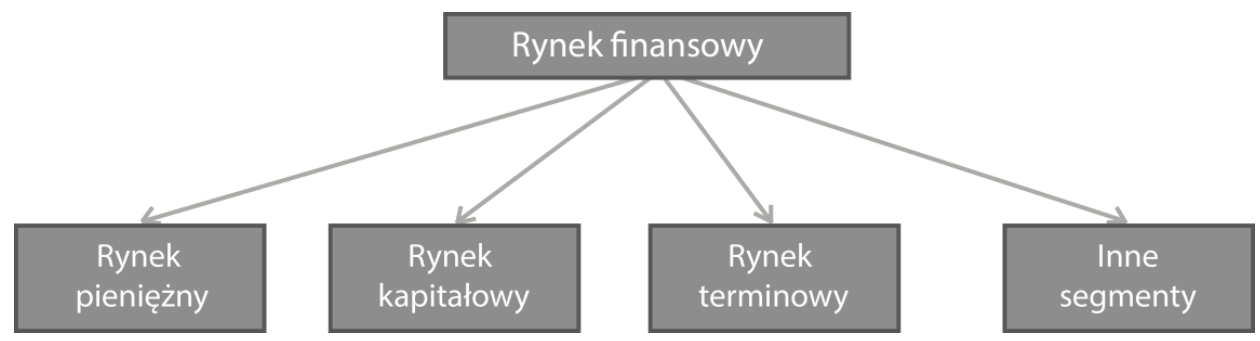

Schemat 1. Podział pionowy rynku finansowego

Źródło: opracowanie własne na podstawie: Frańczuk i Gałązka [2014: 19].

Konsument chcąc korzystać z usług danego podmiotu zawiera z nią umowę. Umowa według prawa cywilnego to zgodne porozumienie dwóch lub więcej stron ustalające ich wzajemne prawa lub obowiązki. W kontekście rynku terminowego umowa, to nic innego jak możliwość zawierania transakcji na instrumentach finansowych poprzez podmiot inwestycyjny [Kamińska 2013: 67]. Zatem, aby rynek ten dobrze funkcjonował zapewniona musi być gwarancja należytego wykonywania tychże umów.

Celem niniejszego referatu jest: przedstawienie prawnych i ekonomicznych aspektów ochrony konsumentów na rynku terminowym w Polsce i na świecie, w tym wyjaśnienie Dyrektyw MiFID oraz MiFID II; zobrazowanie kwestii nadzoru; refleksje na temat możliwości informowania konsumenta na polskim rynku terminowym; zaprezentowanie jak ochrona prawna i ekonomiczna wygląda w Unii Europejskiej i na świecie. Omówiony został także wątek ogólnych relacji pomiędzy konsumentem, a podmiotami inwestycyjnymi (polskimi i zagranicznymi), ponadto jak takie relacje wpływają na klarowność rynku terminowego.

Do stworzenia niniejszej pracy zostały wykorzystane metody obserwacyjne, a także metody intuicyjne, ponieważ argumenty do twierdzeń ogólnych są czerpane z doświadczenia osobistego Autora.

Główną hipotezą artykułu, jest pytanie czy wzrost znaczenia rynku terminowego w Polsce i na świecie, a także złożoności instrumentów i mechanizmów rynkowych, wymusza konieczność stałej kontroli nadzoru polskiego czy europejskiego, a także czy najnowsze wprowadzane zmiany prawne i rozwiązania ekonomiczne są niezbędne do skutecznej ochrony konsumenta na rynku terminowym, a jeśli tak - to jakie skutki za sobą pociągają i jaki mają wpływ na konsumenta rynku terminowego. 


\section{ASPEKTY OCHRONY KONSUMENTA NA RYNKU TERMINOWYM}

Do prawnych aspektów ochrony konsumenta na rynku terminowym w Polsce i na świecie zalicza się m.in.:

- nowelizacja unijnej Dyrektywy w sprawie rynków instrumentów finansowych MiFID, a następnie zaktualizowanie jej do MiFID II,

- najnowsze zmiany w Ustawie o obrocie instrumentami finansowymi, które zostaną wprowadzone dnia 29 kwietnia 2017 r.,

- zwiększenie ilości możliwości rozwiązywania sporów między konsumentem, a podmiotem brokerskim polskim i zagranicznym m.in. poprzez wprowadzenie nowego trybu rozwiązywania spraw polubownie przed Rzecznikiem Finansowym,

- istnienie systemu gwarantowania depozytów,

- zapewnienie nadzoru nad rynkiem terminowym, w tym działania nadzoru służące do zwiększenia skuteczności ochrony konsumenta na rynku terminowym.

Do ekonomicznych aspektów ochrony konsumenta na rynku terminowym w Polsce i na świecie, które pośrednio wynikają z powyższych aspektów zalicza się m.in.:

- większą przejrzystość rynku terminowego dla inwestorów,

- udostępnienie wielu informacji na temat struktury inwestorów, dzięki której inwestor może lepiej ocenić ryzyko danych walorów inwestycyjnych obowiązek ten mają także podmioty zagraniczne,

- obowiązek uświadomienia inwestorów swoich praw dotyczących kwestii polubownego rozwiązywania sporów, (wprowadzony przez Dyrektywę MiFID II),

- ułatwienie procesów reklamacyjnych prowadzonych z podmiotami polskimi,

- większa klarowność Alternatywnego Systemu Obrotu NewConnect,

- skuteczniejsze spełnianie funkcji alokacyjnej rynku terminowego poprzez zwiększenie świadomości inwestorskiej - przede wszystkim w przypadku podmiotów zagranicznych.

\section{DYREKTYWA MiFID ORAZ MiFID II}

MiFID [Dyrektywa 2004/39/WE Parlamentu Europejskiego i Rady z dnia 21 kwietnia 2004 r. ... (Dyrektywa w sprawie rynków instrumentów finansowych; $\mathrm{z}$ ang. Markets in Financial Instruments Directive) jest to dyrektywa, której głównym celem ustanowienia jest zwiększenie i regulacja konkurencji rynkowej oraz ochrony klientów na europejskich rynkach finansowych usług inwestycyjnych [Valiante 2011: 18]. 
Główne założenia Dyrektywy MiFID to [Investment services..., dostęp: 14.03.2017]:

- rozszerzenie zasady jednolitego paszportu,

- uaktualnienie i poszerzenie przepisów o ochronie praw inwestorów,

- podział klientów ze względu na posiadaną wiedzę oraz doświadczenie inwestycyjne, aby umożliwić podjęcie świadomej decyzji inwestycyjnej,

- zwiększenie konkurencyjności na rynku obrotu instrumentów finansowych,

- objęcie nadzorem usług doradztwa inwestycyjnego,

- dostęp do pełnej historii zrealizowanych transakcji wraz z wszystkimi danymi na ich temat - dyrektywa wymaga, aby przedsiębiorstwa inwestycyjne przechowywały wszystkie dane dotyczące zawieranych transakcji przez okres przynajmniej 5 lat,

- zwiększenie spójności i przejrzystości funkcjonowania firm,

- obowiązek „najlepszego wykonania” - realizowanie zleceń po najbardziej korzystnych warunkach, wraz z pełnym udokumentowaniem procesu.

Wytyczne MiFID obejmują [Investment services..., dostęp: 14.03.2017]:

- banki,

- brokerów,

- giełdy,

- doradców inwestycyjnych,

- większość instytucji świadczących usługi finansowe na rynku kapitałowym.

Instrumenty finansowe, do których mają zastosowanie przepisy MiFID to zbywalne papiery wartościowe (w tym akcje), instrumenty rynku pieniężnego, jednostki funduszy inwestycyjnych, walutowe kontrakty terminowe typu forward, walutowe transakcje opcyjne, umowy terminowe na stopę procentową oraz instrumenty pochodne dotyczące przenoszenia ryzyka kredytowego [New rules for more efficient..., dostęp: 14.03.2017].

MiFID II, znowelizowana dyrektywa w sprawie regulacji rynku instrumentów finansowych, dyrektywa unijna regulująca kwestię świadczenia usług finansowych w krajach europejskich, w znacznym stopniu modyfikuje wymogi $\mathrm{Mi}$ FID oraz wprowadza zmiany w regulacjach dotyczących oferowania instrumentów finansowych. Rada Unii Europejskiej przyjęła MiFID II dnia 14 marca 2014 roku [Dyrektywa Parlamentu Europejskiego i Rady 2014/65/UE z dnia 15 maja 2014 r. ...].

Co wynika z powyższej dyrektywy, wraz z końcem lipca 2017 roku wszystkie kraje członkowskie UE mają obowiązek wprowadzić regulacje MiFID II, które będą obowiązywać od początku 2018 roku [Investment services..., dostęp: 14.03.2017]. Brokerzy świadczący usługi handlu na rynku Forex lub kontraktach różnicy kursowych (CFD) nie będą mogły świadczyć tych usług na terenie Europy, jeśli nie będą spełniać założeń regulacji MiFID II. 
Największą korzyścią wynikającą $\mathrm{z}$ dyrektywy jest wspomniana wyżej zwiększona klarowność rynku terminowego, a także odcięcie od europejskiego (w tym polskiego) rynku finansowego podmiotów, które dość agresywnie reklamują się m.in. w Polsce, a nie będą w stanie dostosować się do regulacji. Przede wszystkim dotyczy to brokerów wobec których, nawet w Polsce, toczy się wiele postępowań w prokuraturach.

Kontrowersje wzbudza fakt, że na poziomie lokalnym w Europie istnieją pewne znaczące różnice $\mathrm{w}$ różnych nadzorach finansowych, w tym i w Polsce. Może to oznaczać, że niektórym podmiotom, które mają znaczącą pozycje na rynku może być nieopłacalne dostosowanie się do regulacji w Polsce, w Niemczech itp. Taki broker może zdecydować się na zaprzestanie świadczenia usług dla obywateli tych krajów, co w praktyce oznacza mniejszy wybór podmiotów [MIFiD: narzędzie..., dostęp: 14.03.2017].

Regulacje te jednak najbardziej mogą uderzyć w rodzimych brokerów ze względu na kwestie techniczne, biurokrację, a także koszty wprowadzenia i dostosowania się do regulacji. Każdy broker będzie zobowiązany do nagrywania rozmów telefonicznych z klientami, co znacznie ułatwi dochodzenie swoich praw przed sądem. Sam MiFID II wśród środowiska brokerskiego uważany jest za bardzo radykalne rozwiązanie.

Istotną komplikacją jest kwestia brytyjska. W przypadku zakończenia procesu wyjścia Wielkiej Brytanii z UE, (przy założeniu, że MiFID II nie zostanie zmieniony) to brokerzy, którzy świadczą swoje usługi na kontynencie i nie dostosują się do zaleceń MIFiD II mogą mieć problem z kontynuowaniem działalności. Dotyczy to przede wszystkim brokerów działających w modelu marketmaker (opisany w późniejszej części referatu).

Do zmian tych szybciej mogą dostosować się podmioty świadczące usługi w modelu MTF - ponieważ ideą założenia stworzenia modelu przez Dyrektywą MiFID już było zapewnienie całkowitej transparentności w handlu i zapewnienie uporządkowanego obrotu [Herbst 2014: 4]. Broker MTF oferuje swoim klientom dostęp do arkusza zleceń zawierającego tylko i wyłącznie wiążące zlecenia $\mathrm{z}$ limitem. Jego wynagrodzeniem jest z kolei prowizja od obrotu. Broker nie jest stroną tu transakcji oraz dodatkowo wyklucza zjawisko „last look“, co w teorii zmniejsza szansę na wystąpienie poślizgu cenowego przy natychmiastowej realizacji zleceń [Typy brokerów, dostęp: 14.03.2017].

Należy również wspomnieć, że wraz z wprowadzeniem dyrektywy MiFID II wycofane zostaną usługi brokerów świadczących możliwość handlu na rynku za pomocą kont typu: mini, micro, nano. Konta te charakteryzują się tym, że depozyt wymagany do rozpoczęcia spekulacji jest bardzo mały [The Practical Implications of MiFID II: Third..., dostęp: 14.03.2017]. Problem ten dotknie na pewno konsumentów, którzy nie posiadają dużego kapitału na spekulacje. Jednak zaletą tego rozwiązania jest to, że inwestor będzie na pewno ostrożniej działał na 
rynku finansowym ze względu na większe potencjalne straty, który można na tym rynku ponieść z większym depozytem [The Practical Implications of MiFID II, dostęp: 14.03.2017].

Brokerzy po wprowadzeniu dyrektywy MiFID II są zobowiązani również ujawniać na bieżąco kwartalne statystyki na temat procentu zyskownych i stratnych kont inwestorów, gdzie konta te muszą być posegregowane ze względu na typ instrumentu przeznaczony do handlu, np. Forex, akcje itp.

Przykładowe informacje dotyczące wyników osiąganych przez klientów Domu Maklerskiego Banku Ochrony Środowiska S.A. na instrumentach Finansowych na rynku OTC, w podziale na grupy instrumentów, za IV kwartał 2016 r. zawarte są w tabeli 1.

Tabela 1. Wyniki osiągane przez klientów w IV kwartale 2016 w podziale na grupy instrumentów

\begin{tabular}{|l|c|c|c|}
\hline $\begin{array}{c}\text { Typ instrumentu } \\
\text { finansowego }\end{array}$ & $\begin{array}{c}\text { Procent kont, na } \\
\text { których wykazano } \\
\text { zysk }\end{array}$ & $\begin{array}{c}\text { Procent kont na } \\
\text { których nie wykaza- } \\
\text { no zysku lub straty }\end{array}$ & $\begin{array}{c}\text { Procent kont, na } \\
\text { których wykazano } \\
\text { stratę }\end{array}$ \\
\hline Bond/Interest Rate CFD & 40,95 & 0,95 & 58,10 \\
\hline Commodity CFD & 38,69 & 0,20 & 61,11 \\
\hline Equity CFD & 41,98 & 0,00 & 58,02 \\
\hline Forex CFD & 35,35 & 0,04 & 64,61 \\
\hline Index CFD & 40,33 & 0,31 & 59,36 \\
\hline
\end{tabular}

Źródło: opracowanie własne na podstawie informacji Domu Maklerskiego Banku Ochrony Środowiska S.A. [Statystyki klientów, dostęp: 14.03.2017].

MiFID oraz MiFID II bez wątpienia są dyrektywami, która wprowadzają wiele porządku na europejskim rynku terminowy - świadczą o tym wyżej wymienione główne założenia Dyrektywy. Wprowadzenie nowych zasad w kontekście ochrony inwestorów, struktury rynku, wymogów informacyjnych, doradztwa inwestycyjnego, a także wymogi technologiczne (np. związane z tradingiem algorytmicznym oraz raportowaniem) bez wątpienia można uznać za dobry krok w kierunku ochrony konsumenta przed nieuczciwymi działaniami ze strony podmiotów inwestycyjnych [MiFID II, dostęp: 14.03.2017].

Większa klarowność rynku finansowego, większa kontrola podmiotów brokerskich, doradców inwestycyjnych, konieczność publikowania szczegółowych statystyk na pewno sprawi, że konsumenci będą lepiej poinformowani na temat możliwości spekulowania na rynku finansowym, co sprawi, że będą lepiej na tym rynku chronieni przed nieuczciwymi praktykami. Być może przemyślą wcześniej swoje działania i będą mogli łatwiej wybrać odpowiedniego doradcę inwestycyjnego lub skuteczniej spekulować na swój rachunek, co może zwiększyć procentową strukturę zyskownych kont brokerskich. 


\section{NOWELIZACJA USTAWY O OBROCIE INSTRUMENTAMI FINANSOWYMI}

Sejm uchwalił rządowy projekt nowelizacji ustawy o obrocie instrumentami finansowymi oraz niektórych innych ustaw dotyczący m.in.:

- zniesienie podziału rynku regulowanego na rynek giełdowy i rynek pozagiełdowy [Art. 1 pkt. 10 Projektu ustawy o zmianie ustawy o obrocie instrumentami finansowymi...],

- wprowadzenie regulacji dotyczących instytucji rachunku derywatów [Art. 1 pkt. 2 Projektu ustawy o zmianie ustawy o obrocie instrumentami finansowymi...],

- zmianę organu wydającego zezwolenie na prowadzenie giełdy [Art. 14 Projektu ustawy o zmianie ustawy o obrocie instrumentami finansowymi...],

- wskazanie czynności, które mogą być wyłącznie wykonywane przez agenta firmy inwestycyjnej [Art. 1 pkt. 31 Projektu ustawy o zmianie ustawy o obrocie instrumentami finansowymi...].

Projekt ten został zatwierdzony przez Senat, a w dniu 14 kwietnia 2017 r. w Dzienniku Ustaw pod poz. 791 opublikowana została ustawa z dnia 9 marca 2017 r. o zmianie ustawy o obrocie instrumentami finansowymi oraz niektórych innych ustaw (Nowelizacja). Zmodyfikowane przepisy ustawy o obrocie instrumentami finansowymi (Ustawa) wejdą w życie po upływie 14 dni od dnia ogłoszenia w Dzienniku, tzn. od dnia 29 kwietnia 2017 r. [Zamknięty katalog podmiotów..., dostęp: 14.03.2017]

Zasadniczym celem zmiany organu wydającego zezwolenie na prowadzenie rynku regulowanego z ministra właściwego do spraw instytucji finansowych na Komisję Nadzoru Finansowego (KNF) jest skrócenie procesu licencjonowania w Polsce giełd instrumentów finansowych oraz skupienie spraw związanych $\mathrm{z}$ nadzorem nad rynkiem kapitałowym w całości w ustawowo powołanym do tego organie, jakim jest Komisja Nadzoru Finansowego ${ }^{1}$.

Z kolei faktyczne różnice między rynkiem giełdowym a rynkiem pozagiełdowym nie są wystarczająco istotne, aby uznać za uzasadnione rozróżnienie dwóch podtypów rynku regulowanego; pozostawienie takiego zróżnicowania miałoby sens, gdyby w stosunku do rynku pozagiełdowego przewidziane byłyby istotnie mniejsze wymogi i uproszczone zasady funkcjonowania w porównaniu $\mathrm{z}$ rynkiem giełdowym ${ }^{2}$.

Firma inwestycyjna może, w drodze umowy zawartej w formie pisemnej, powierzyć osobie fizycznej, osobie prawnej lub jednostce organizacyjnej nieposiadającej osobowości prawnej stałe lub okresowe wykonywanie w imieniu i na

1 Potrzeba i cel wydania projektowanej ustawy [w:] Uzasadnieniu do Projetu ustawy o zmianie ustawy o obrocie instrumentami finansowymi...

${ }^{2}$ Przedstawienie aktualnego stanu prawnego [w:] Uzasadnieniu do Projekcie ustawy o zmianie ustawy o obrocie instrumentami finansowymi... 
rachunek firmy inwestycyjnej czynności pośrednictwa w zakresie działalności maklerskiej prowadzonej przez tę firmę inwestycyjną (agent firmy inwestycyjnej) [Art. 1 pkt. 31 lit. a ust. 1 Projektu ustawy o zmianie ustawy o obrocie instrumentami finansowymi...]. Czynności te związane są z pozyskiwaniem klientów lub potencjalnych klientów, z zawieraniem umów o świadczenie usług maklerskich oraz umożliwiające realizację umów o świadczenie usług maklerskich, w szczególności polegające na przyjmowaniu zleceń [Art. 1 pkt. 31 lit. a ust. 2 Projektu ustawy o zmianie ustawy o obrocie instrumentami finansowymi...].

Co istotne, od 29 kwietnia 2017 r. czynności, wyżej wymienione, mogą być wykonywane wyłącznie przez firmę inwestycyjną lub agenta firmy inwestycyjnej [Art. 1 pkt. 31 lit. b Projektu ustawy o zmianie ustawy o obrocie instrumentami finansowymi...].

Zmiana ta oznacza, że każda sprzedaż bezpośrednia, która oferuje jakąkolwiek inwestycje jest już regulowana. Oznacza to także, że osoba która może legalnie takie czynności wykonywać musi być pracownikiem firmy inwestycyjnej (która jest pod regulacją) lub posiadać licencję agenta firmy inwestycyjnej. Agent ten może być pośrednikiem tylko i wyłącznie dla jednej firmy inwestycyjnej. Agent na żądanie konsumenta musi przedstawić swoje imię i nazwisko oraz informację o tym, czy jest on wpisany na listę agentów firm inwestycyjnych prowadzoną przez Komisję Nadzoru Finansowego [Agenci firm inwestycyjnych..., dostęp: 14.03.2017].

Zmiany te nie dotyczą sytuacji, kiedy informacje przekazywane są jednocześnie do szerokiej grupy klientów lub potencjalnych klientów firmy inwestycyjnej, albo do nieokreślonego adresata [Art. 79 ust. 2b Ustawy z dnia 29 lipca 2005 r. ...].

\section{ROZWIĄZYWANIE SPORÓW MIĘDZY KONSUMENTEM A PODMIOTEM BROKERSKIM POLSKIM I ZAGRANICZNYM}

Aby być chronionym na rynku terminowym przez nadzór w Polsce - do spekulacji na własny rachunek należy wybierać wyłącznie polskie podmioty, ponieważ to one są regulowane polskimi przepisami prawa. Jeżeli jednak broker ma siedzibę na terenie UE, zalecenia oraz wytyczne wynikające z MiFID II są dla tych podmiotów obowiązujące. Komplikacje mogą pojawić się w momencie wybrania podmiotu spoza UE, ponieważ podmioty te nie są nadzorowane przez Komisję Nadzoru Finansowego [Podmioty nadzorowane, dostęp: 14.03.2017].

Wybór podmiotu zagranicznego może spowodować, że w przypadku zaistnienia sporu ten może okazać się praktycznie niemożliwy do rozwiązania - ze względu na brak nadzoru, brak pomocy jakichkolwiek instytucji czy wreszcie koszty postępowania, w zdecydowanej większości przypadków w przypadku wstępnej kalkulacji przekraczający wartość potencjalnego sporu. Większość 
polskich brokerów zapewnia możliwość polubownego rozwiązania sporu. W przypadku podmiotów spoza UE jest to niezwykle utrudnione, wręcz niemożliwe. Nie wszystkie sprawy można rozwiązać polubownie i niekiedy trzeba skierować sprawę do sądu - ale w przypadku polskich podmiotów jest to znacznie uproszczone.

Nie oznacza to, że wszystkie podmioty zagraniczne i stosowane przez poszczególne kraje rozwiązania i procedury są nieodpowiednie. Inaczej może być w niektórych przypadkach, np. w przypadku brokerów australijskich. W Australii w odróżnieniu do Polski - tamtejszy Rzecznik Finansowy prowadząc postępowanie mediacyjne i wydajać na koniec tego postępowania decyzję wydaje decyzję wiążącą, zastępującą praktycznie zastępuje orzeczenie sądu [What we do, dostęp: 14.03.2017]. Praktycznie rzecz ujmując, inwestor, konsument rynku terminowego, jeśli złoży wniosek w danej sprawie do tamtejszego Rzecznika Finansowego i decyzja będzie tego inwestora satysfakcjonowała, to nie będzie on zmuszony występować na drogę sądową - znacznie droższą i bardziej czasochłonną.

W Polsce został wprowadzony również podobny tryb rozwiązywania spraw polubownie przed Rzecznikiem Finansowym [Wnioski w sprawie rozwiąywania sporów..., dostęp: 14.03.2017], ale niestety Rzecznik nadal nie posiada decydującego głosu w danej sprawie i może wyłącznie proponować pewne rozwiązania dotyczące danej kwestii. Wydaje on na koniec postępowania opinię, która może być uwzględniona przez sąd, ale nie musi. Oznacza to w niektórych przypadkach konieczność wystąpienia na drogę sądową i zaangażowania organów wymiaru sprawiedliwości.

Co warte odnotowania, podmioty rynku terminowego będą musiały informować przy zawieraniu umowy swoich klientów o możliwości polubownego rozwiązywania sporów przy Rzeczniku Finansowym. To postępowanie będzie też wskazane jako dedykowane sporom dotyczącym kwestii szeroko pojętych usług finansowych, w rejestrze prowadzonym przez UOKiK [Latwiej o polubowne rozwiąanie sporu, dostęp: 14.03.2017].

Cechy postępowania polubownego przy Rzeczniku Finansowym³

- obowiązek przystąpienia podmiotu rynku finansowego do postępowania,

- połączenie najlepszych cech mediacji i koncyliacji w ramach postępowania - najpierw następuje próba zbliżenia stanowisk stron sporu (jak w mediacji), a jeśli to nie przynosi efektu przedstawiana jest stronom propozycja rozwiązania sporu,

- celem postępowania jest ugoda, więc każda ze stron musi być gotowa na ustępstwa,

- poufność postępowania (zwiększa skłonność instytucji finansowych do ugód).

${ }^{3}$ Najważniejsze cechy postępowania polubownego przy Rzeczniku Finansowym, [w:] Latwiej o polubowne rozwiazanie sporu [dostęp: 14.03.2017]. 
W przypadkach inwestowania u podmiotów zagranicznych należy ustalić:

- który sąd jest w danej sprawie kompetentny - polski czy zagraniczny,

- które prawo jest właściwe - polskie czy zagraniczne. Może tutaj także dojść do sytuacji, w której polski sąd wydaje wyrok na podstawie prawa zagranicznego.

\section{PRAWA KONSUMENTA NA RYNKU TERMINOWYM W PRZYPADKU POTENCJALNEGO UPADKU PODMIOTU BROKERSKIEGO}

Ochrona prawna w przypadku potencjalnego upadku podmiotu brokerskiego jest zapewniona przez Krajowy Depozyt Papierów Wartościowych poprzez System Gwarancyjny. Gwarantuje on pewien procent zwrotu utraconych środków w zależności od depozytu. Zagadnienie to przedstawia tabela 2.

Tabela 2. System gwarantowania depozytów zapewniony przez KDPW

\begin{tabular}{|c|c|}
\hline Procent zwrotu utraconych środków & Kwota \\
\hline $100 \%$ & 0 EUR - 3 000 EUR \\
\hline $90 \%$ & 3000 EUR - 22 000 EUR \\
\hline $0 \%$ & 22000 EUR i więcej \\
\hline
\end{tabular}

Źródło: opracowanie własne na podstawie danych z KDPW [Nowy system gwarantowania rozliczeń, dostęp: 14.03.2017].

W przypadku roszczenia większego niż 3000 EUR, w części roszczenia mniejszej niż 3000 EUR otrzymamy w 100\%, a większej niż 3000 EUR 90\% lub nawet $0 \%$. Niestety, jest to stosunkowo niewiele, ponieważ w przypadku chociażby lokat bankowych, klient banku jest chroniony w wysokości do poziomu aż 100000 EUR [Kwota objęta gwarancja, dostęp: 14.03.2017].

\section{BROKER TYPU MARKET-MAKER, KWESTIA SALD DEBETOWYCH I ZWAZZANA Z TYM OCHRONA KONSUMENTA}

Broker market-maker jest to broker, który występuje jako organizator własnego rynku dla uczestników, korzystając z kwotowań rynku międzybankowego [Market Maker..., dostęp: 14.03.2017].

Jeśli chcemy dowiedzieć się, czy broker zapewnia nam ochronę przed saldem ujemnym, który może powstać w wyniku różnych anomalii rynkowych należy przeczytać regulamin świadczenia usług przez konkretny podmiot. Fak- 
tem jednak jest, że mała liczba podmiotów, szczególnie polskich, posiada ochronę przed saldem debetowym.

Jeśli inwestor zamierza spekulować mniejszym depozytem, potencjalne ryzyko wynikające z potencjalnego sporu może okazać się mniejsze niż korzyści wynikające z posiadania ochrony przed saldem debetowym. Należy tu oczywiście rozgraniczać sytuacje, w których saldo to wynika z faktycznego działania rynkowego i ruch cenowy, który taki debet spowodował jest zgodny z ruchem na rynku rzeczywistym, a takimi sytuacjami, w której broker działa rażąco na niekorzyść konsumenta.

\section{REKLAMACJE DOTYCZĄCE SPREADU}

Należy na początku, wyjaśnić czym jest spread. Spread to nic innego jak różnica pomiędzy kursem (ceną) sprzedaży a kursem (ceną) kupna aktywów (np. walut, papierów wartościowych, towarów) [Reuters Limited 1992: 150].

Problem ze spreadem polega przede wszystkim na tym, że zakładając w danym podmiocie brokerskim rachunek demonstracyjny, rzadko jesteśmy w stanie sprawdzić rzeczywiste koszty występujące na rachunkach rzeczywistych. Przeważnie na rachunkach demonstracyjnych spready te są korzystniejsze. Brokerzy na rachunkach rzeczywistych bardzo często ten spread rozszerzają - przypadki te $\mathrm{w}$ różnych sytuacjach są uzasadnione, np. przed pojawieniem się amerykańskich danych z rynku pracy, np. payrolls. Zmiany te praktycznie nie występują na rachunkach demonstracyjnych.

Jeżeli jednak według obiektywnych przesłanek pogorszenie warunków handlu (a to bez wątpienia jest skutkiem rozszerzenia spreadu) nie jest uzasadnione rynkowo, takie działanie może nosić znamiona przestępstwa i powinno być reklamowane. $\mathrm{Z}$ kolei $\mathrm{w}$ przypadku niezadowolenia $\mathrm{z}$ polubownej drogi rozwiązywania sprawy należy zawiadomić odpowiednie organy nadzoru.

\section{NADZÓR NAD RYNKIEM TERMINOWYM I JEGO DZIAŁANIA SŁUŻĄCE DO ZWIĘKSZENIA SKUTECZNOŚCI OCHRONY KONSUMENTA NA TYM RYNKU}

Organem nadzorczym w Polsce jest Komisja Nadzoru Finansowego, w skrócie KNF. Jest to centralny organ administracji rządowej sprawujący przede wszystkim (ale nie tylko) nadzór nad rynkiem finansowym, terminowym w Polsce. Nadzór nad działalnością Komisji sprawuje Prezes Rady Ministrów [O Komisji, dostęp: 14.03.2017].

KNF nadzoruje rożne sektory związane $\mathrm{z}$ rynkiem finansowym, jak na przykład rynek NewConnect. W 2007 roku Giełda Papierów Wartościowych 
w Warszawie powołała do życia Alternatywny System Obrotu NewConnect. Rynek ten przeznaczony jest dla powstających bądź młodych spółek o stosunkowo niewielkiej przewidywanej kapitalizacji działających przede wszystkim w sektorach tzw. nowych technologii: IT, media elektroniczne, biotechnologia, energia alternatywna itp., opartych głównie na aktywach niematerialnych [O rynku, dostęp: 14.03.2017].

KNF wraz ze współpracą z Giełdą Papierów Wartościowych monitoruje spółki, w które konsument rynku terminowego ma możliwość zainwestować i ich wywiązywanie się z obowiązków m.in. dotyczących wymogów informacyjnych. Warty odnotowania jest fakt, że od 2012 roku zarząd GPW wykluczył z obrotu ponad 100 spółek [Statystyki rynku - roczne, dostęp: 14.03.2017].

Dla konsumentów rynku terminowego oznacza to większe bezpieczeństwo inwestycji w innowacyjne biznesy, a w połączeniu $\mathrm{z}$ doborem odpowiednich spółek, które te wymogi spełniają może być atrakcyjne.

KNF w zakresie ochrony konsumenta na rynku terminowym prowadzi również Listę Ostrzeżeń Publicznych [Lista ostrzeżeń publicznych Komisji Nadzoru Finansowego, dostęp: 14.03.2017]. Lista ta informuje o tym, wobec działalności których spółek złożono zawiadomienie o możliwości popełnienia przestępstwa. Lista ta nie oznacza, że spółki zostały już skazane prawomocnym wyrokiem, dlatego należy podchodzić do każdej sprawy indywidualnie. Mimo to prowadzenie takiej listy daje konsumentowi możliwość weryfikacji różnych podmiotów, w tym podmiotów inwestycyjnych.

\section{PODSUMOWANIE}

Podsumowując niniejszy referat należy zauważyć, że inwestor, spekulant na rynku terminowym jest bez wątpienia konsumentem tego rynku - na podstawie prawa polskiego - a dokładnie Kodeksu Cywilnego oraz innych ustaw. Przysługuje mu zatem pełna ochrona praw konsumenckich na tym rynku.

Odnosząc się do hipotezy postawionej we wstępie można zorientować się, że praktyka i problemy inwestorów pokazują, jak kwestia ochrony i zapewnienia nadzoru jest ważna dla konsumenta. Świadczą o tym powyższe rozważania, a także pozostałe przypadki jak, np. zawieszenie w marcu 2017 roku działalności podmiotu HFT Brokers przez KNF na podstawie prowadzonego postępowania administracyjnego za nieprzestrzeganie przepisów [HFT Brokers zawieszone..., dostęp: 14.03.2017].

Niektóre podmioty i interpretacje próbują podważać to, że inwestor nie jest konsumentem, ponieważ prowadzi działalność zarobkową (zarabia lub próbuje zarabiać na rynku terminowym). Takie działania należy stanowczo zwalczać, ponieważ są one absurdalne - chociażby ze względu na to, że takim konsumen- 
tem nie mógłby być także klient posiadający oprocentowany rachunek bankowy czy lokatę bankową, ponieważ celem założenia lokaty jest zarobek. Nadzór, dostęp informacyjny, rozwój porząaku prawnego na pewno pomaga podnosić świadomość konsumentów w celu zwiększenia ich bezpieczeństwa oraz ochrony ich depozytów.

\section{BIBLIOGRAFIA}

Agenci firm inwestycyjnych - osoby fizyczne, Komisja nadzoru Finansowego, https://www.knf.gov.pl/ dla_rynku/PODMIOTY_rynku/Podmioty_rynku_kapitalowego/AgenciFirmInw.html.

Akty prawne rynku kapitałowego, Komisja Nadzoru Finansowego, https://www.knf.gov.pl/regu lacje/regulacje_prawne/Akty_prawne/index.html.

Dyrektywa 2004/39/WE Parlamentu Europejskiego i Rady z dnia 21 kwietnia 2004 r. w sprawie rynków instrumentów finansowych.

Dyrektywa Parlamentu Europejskiego i Rady 2014/65/UE z dnia 15 maja 2014 r. w sprawie rynków instrumentów finansowych

Frańczuk M., Gałązka K., 2014, Teoria finansów, rynek finansowy, [w:] A. Paździor (red.), Finanse. Funkcjonowanie, instytucje i instrumenty rynku finansowego, finanse publiczne przedsiębiorstw i gospodarstw domowych, Politechnika Lubelska, Lublin.

Herbst J., 2014, MiFID II / MiFIR: Your Survival Guide. Market Structures, Norton Rose Fulbright LLP, Australia.

HFT Brokers zawieszone. Urzędnicy byli jednomyślni, Grupa Wirtualna Polska S.A, http://www.money.pl/gielda/wiadomosci/artykul/knf-zawiesila-dzialalnosc-maklerska-hft,63,0, 2279743.html.

Investment services and regulated markets - Markets in financial instruments directive (MiFID), The European Commission, https://ec.europa.eu/info/business-economy-euro/banking-andfinance/financial-markets/securities-markets/investment-services-and-regulated-markets-marketsfinancial-instruments-directive-mifid_en.

Kamińska M., 2013, Czynności prawne, [w:] K. Brzeziński (red.), Prawo cywilne. Czesść ogólna, Wolters Kluwer Polska SA, Warszawa.

Kwota objęta gwarancja, Bankowy Fundusz Gwarancyjny, https://www.bfg.pl/.

Lista ostrzeżeń publicznych Komisji Nadzoru Finansowego, Komisja Nadzoru Finansowego, https://www.knf.gov.pl/o_nas/ostrzezenia_publiczne/lista_ostrzezenia.html.

Łatwiej o polubowne rozwiazanie sporu, Rzecznik Finansowy, https://rf.gov.pl/sprawy-biezace/ Latwiej_o_polubowne_rozwiazanie_sporu_22501

Market Maker, ECN - modele dziatania brokerów FX, Dom Maklerski Banku Ochrony Środowiska S.A., http://bossafx.pl/index.jsp?layout=fx_2a\&page=0\&news_cat_id=3799\&news_id=34557.

MiFID II, PwC Polska, https://www.pwc.pl/pl/sektor-finansowy/regulacje/mifid-ii.html.

MIFiD: narzędzie, które nie zwalnia od myślenia, Bonnier Business Polska, https://www.bankier.pl/ wiadomosc/MIFiD-narzedzie-ktore-nie-zwalnia-od-myslenia-2184587.html.

New rules for more efficient, resilient and transparent financial markets in Europe, The European Commission, https://europa.eu/rapid/press-release_IP-11-1219_en.html

Nowy system gwarantowania rozliczeń, Krajowy Depozyt Papierów Wartościowych, https://www.kdpwccp.pl.

O Komisji, Komisja Nadzoru Finansowego, https://www.knf.gov.pl/o_nas/komisja/index.html.

O rynku, NewConnect, http://www.newconnect.pl/index.php?page=o_rynku. 
Podmioty nadzorowane, Komisja Nadzoru Finansowego, https://www.knf.gov.pl/dane_wspolne/ podmioty.html.

The Practical Implications of MiFID II, LK Shields, https://www.lkshields.ie/news-insights/pub lication/the-practical-implications-of-mifid-ii.

The Practical Implications of MiFID II: Third Country Firms, Globe Business Media Group, https://www.lexology.com/library/detail.aspx?g=f25506c5-681a-4575-b67d-74f2512f5c69.

Projekt ustawy o zmianie ustawy o obrocie instrumentami finansowymi oraz niektórych innych ustaw z projektami aktów wykonawczych (druk nr 991).

Reuters Limited, 1992, Stownik Reutera: Międzynarodowe terminy ekonomiczne i finansowe, Powszechna Agencja Informacyjna, Warszawa.

Statystyki klientów, Dom Maklerski Banku Ochrony Środowiska S.A., https://bossafx.pl.

Statystyki rynku - roczne, NewConnect, http://www.newconnect.pl/index.php?page=sta-tystyki_ rynku_roczne.

Typy brokerów, Forex Nawigator, http://forex-nawigator.biz/podstawy/brokerzy/typy-brokerow.html. Ustawa z dnia 29 lipca 2005 r. o obrocie instrumentami finansowym, Dz.U. 2005, nr 183, poz. 1538.

Valiante D., 2011, MiFID 2.0 Casting New Light on Europe's Capital Markets, European Capital Markets Institute, Brussels.

What we do, Financial Ombudsman Service Australia, https://fos.org.au/about-us/what-we-do.

Wnioski $w$ sprawie rozwiąywania sporów między klientem a podmiotem rynku finansowego, Rzecznik Finansowy, https://rf.gov.pl/sprawy_biezace/Wnioski_w_sprawie_rozwiazywania_ sporow_miedzy_klientem_a_podmiotem_rynku_finansowego__22239.

Zamknięty katalog podmiotów prowadzacych marketing ushug maklerskich - zmiany w prawie od 29 kwietnia 2017 r., Komisja Nadzoru Finansowego, https://www.knf.gov.pl/o_nas/komuni katy/2017/marketing_uslug_maklerskich.html.

\title{
LEGAL AND ECONOMIC ASPECTS OF CONSUMER PROTECTION IN THE POLISH AND INTERNATIONAL FUTURES MARKET
}

\begin{abstract}
The paper presents the legal and economic aspects of consumer protection in the Polish and international futures market and important issues for the extension of this topic. The purpose of the paper is to clarify the issue of supervision and reflections on the possibility of informing the consumer on the Polish futures market and illustrating how legal and economic protection looks in the EU and in the world. Also discussed is the general relationship between the client and the investment entities (Polish and foreign) and how such relationships affect the clarity of the futures market.
\end{abstract}

Keywords: financial markets, futures market, stock market. 